\title{
Study of Prevalence of Internal Resorption in Periapical Radiography of Anteriors Permanents Tooth
}

\author{
Estudio de la Prevalencia de Reabsorción Interna en Radiografías \\ Periapicales de Dientes Permanentes Anteriores
}

"Lorena Cássia Gueiros de Araújo; *Carol Vasconcelos Lins; *Georgina Agnelo de Lima; *** Rosana Maria Coelho Travassos \& ${ }^{* * *}$ Carla Cabral dos Santos Accioly Lins

\begin{abstract}
ARAÚJO, L. C. G.; LINS, C. V.; LIMA, G. A.; TRAVASSOS, R. M. C. \& LINS, C. C. S. A. Study of prevalence of internal resorption in periapical radiography of anteriors permanents tooth.Int. J. Morphol., 27(1):227-230, 2009.

SUMMARY: The aim of this study was to evaluate, by the use of clinical and radiographic records, the prevalence of internal resorption in anterior permanent teeth of patients from the Clinic of Specialization in Endodontics of Federal University of Pernambuco, Brazil; related to the period of september of 2001 to June of 2007.888 medical records from the archives of the clinic were analyzed. Among them 232 referred to anterior teeth. The presence and the location of the resorption were radiographically observed. The obtained results verified that the internal resorption was prevalent in $2.16 \%$ of the cases, with $0.86 \%$ located in coronal region, $0.44 \%$ in root region and $0.86 \%$ in both regions. We concluded that, despite of being a pathology of low incidence, the knowledge of it is important to the specialist, in order to provide a reliable diagnose and to plan a suitable treatment, once the negligence in a case of internal resorption in anterior permanent teeth can cause the loss of dental element and functional and esthetic alterations in the patient.
\end{abstract}

KEY WORDS: Endodontics; Dental resorption; Prevalence.

\section{INTRODUCTION}

The internal resorption can be called intracanal resorption (Barbosa, 1999) and also canal root resorption (Côrtes \& Bastos, 2004). It is considered as a rare case of resorption (Andreasen \& Andreasen, 1992; Lyroudia et al., 2002; Tsurumaki, 2004), appearing as a typical dystrophy of the pulp which jeopardize the hard tissue of the teeth changing its normal morphology (Trope, 2002).

Its etiology is not quite clarified, however, can be associated with dental traumatism and inflammatory alterations of dental pulp after pulp capping or pulpotomy. Kinomoto et al. (2002), adds that it can also happen due to the infection of dental pulp or extreme heat. These annoying facts stimulate the pulp tissue, thus the inflammatory process starts and then some undifferentiated cells of the pulp can convert themselves to osteoclasts or macrophages, which results in dentinal resorption.
In the majority of the cases, the internal resorption usually is asymptomatic and detectable by routine radiographs (Gunraj \& Washington, 1999; Esberard et al., 2002; Hsien et al., 2003). Radiographically is described as a radiolucent area characterized by an oval-shaped enlargement of the root canal, showing many times the appearance of an ampoule (Hammarstron \& Lindskog, 1985; Gunraj \& Washington; Lopes et al., 2004; Cohenca et al., 2007), and which does not move with variations of radiographic angle (Hsien et al.). In more evolved cases, the fragility of the dental structure can cause areas of fracture or perforation.

The treatment of the resorptions is complex, it demands time, is expensive and its prognostic is unpredictable. One of the reasons that make its prognostic difficult is related to the fact that the periapical radiography emphasizes the observation of two dimensions only and the

\footnotetext{
*Department of Endodontics, Federal University of Pernambuco (UFPE), Brazil.

**Department of Endodontics, University of Pernambuco, Faculty of Odontology (UPE-FOP), Brazil.

***Department of Anatomy, Federal University of Pernambuco (UFPE) and Department of Endodontics, University of Pernambuco, Faculty of Odontology (UPE-FOP) Brazil.
} 
visibility of its length and location is limited, Cohenca et al.

The internal resorption is frequently observed in cervical region but can also occur in all areas of pulp cavity. If it is coronal, the tooth shows pink spots because of the capillary proliferation due to the pulp inflammation (Trope et al., 2000; Esberard et al.). Besides that, its low incidence makes difficult the definition of the area of preference of the pathology. Thus, thistransversal study aims to evaluate the prevalence of internal resorption in anterior permanent teeth of patients from the Clinic of Specialization in Endodontics of Federal University of Pernambuco-Brazil in the last six years.

\section{MATERIAL AND METHOD}

This study follows the rules of search in human beings from National Health Council by the Resolution $N^{\circ} 196 / 96$, in Brazil. The work was sent to the Ethics Committee of Federal University of Pernambuco. It was approved and received the Protocol No 218/07. 888 odontological records from the archives of the Clinic of Specialization in Endodontics of Federal University of Pernambuco-Brazil, were analyzed related to the period of September of 2001 to June of 2007. Among them 232 referred to endodontic treatment realized in anterior permanent teeth (incisor and canines of both dental arches). The clinical data were collected and the initial periapical radiography was chosen to the analysis, which was verified for only one observer, by the use of a negathoscope and a magnifying glass (lupa 10 $\mathrm{X}$, Limat, model 7082), to collect data related to the teeth and it was observed the presence or absence of internal resorption according to its level: coronal, root or both.

\section{RESULTS}

After the analysis of the medical records and by a descriptive statistic, the internal resosrption (Fig. 1) was present in five cases which correspond to $2.16 \%$ of studied sample (Fig. 2). According to its location we found two cases in the coronal region, corresponding to two superior left central incisors $(0.86 \%)$; one in the root region of inferior right central incisor $(0.44 \%)$ and two cases in both regions corresponding to one left central incisor and one left lateral incisor $(0.86 \%)$. The factor trauma was related to one of the five cases of resorption found, once during anamnesis the patient related the occurrence of a bicycle accident with a dental traumatism. It was not possible to establish the etiologic factor of the other four cases once the medical records do not show enough data.

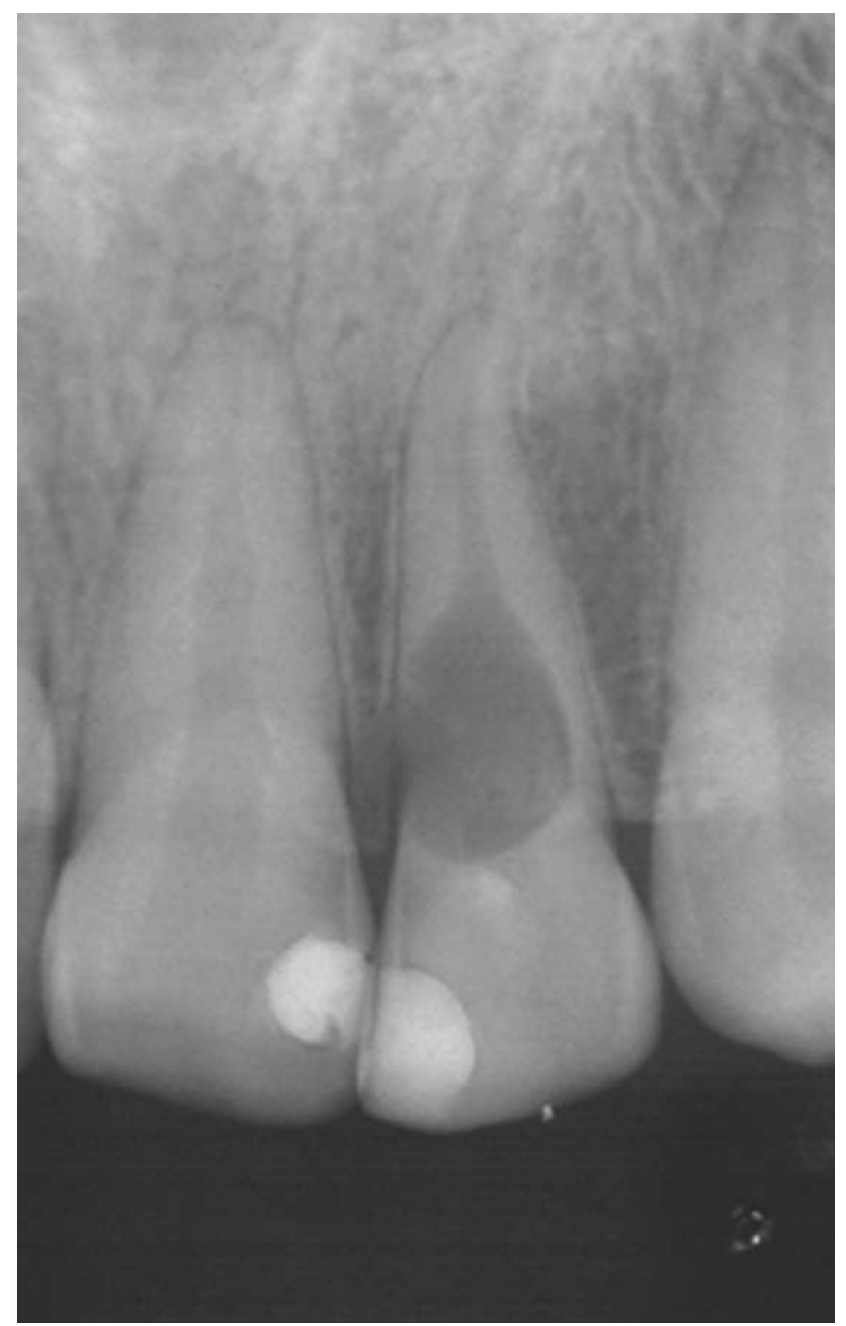

Fig. 1. Radiograph periapical by incisive superior left with internal resorption.

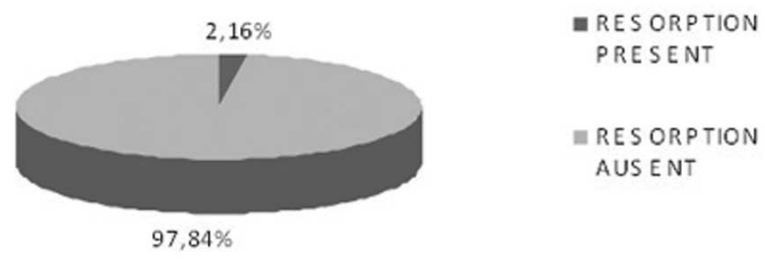

Fig. 2. Prevalence of internal resorption in anteriors permanents tooth, in the Clinic of Specialization in Endodontics of UFPE (20012007).

\section{DISCUSSION}

The internal resorption or canal root resorption (Côrtes \& Bastos; Neville et al. 2004) is a pathology that interests to the endodontic science due to the complexity of 
its treatment Cohenca et al. The great differential in the prognostic of resorptions is directly related to the precocious diagnostic and this one is associated with the correct interpretation of routine radiographs and the follow-up of the cases.

The authors agree that this is a relatively rare pathology (Andreasen \& Andreasen; Lyroudia et al.; Trope; Tsurumaki), therefore, there are few works in the literature that evaluate its incidence, which was observed in our founds.

Concerning about the location, the internal resorption is frequently found in the cervical portion of the coronal region, but it can also be found in any region of the system of root canals (Gunraj \& Washington; Trope et al.; Esberard et al.). Our results are in accordance with the literature once from the five cases found and evaluated, two were located in the coronal region, one in the root region and two in both region; and among the anterior teeth, the incisors were more affected than the canines.

The dental surgeons and specialists in endodontics must know how to diagnose it by simple methods like periapical radiography, which is an easy, available and routine method of the odontological clinic, which can lead the professional to the diagnostic and the follow-up of this pathology. However, it is important to emphasize the restraints of radiographic exams in cases of resorption. This exam allows the visibility of the injury in two dimensions only which makes difficult the choosen of the suitable treatment and many times its diagnostic (Friedland et al., 2001). Besides that, depending on the degree of evolution of the resorption, this one can show a uniform density and this way does not move itself with variations of radiographic angles (Hammarstron \& Lindskog; Esberard et al.; Hsien et $a l$.), which makes more difficult its correct location. Thus, other methods of analysis are found in the literature as complementary options, which we hope it will be available for the specialist in the future: optic microscopy, electronic scanning microscopy, 3D images (Lyroudia et al.) and rotational tomography (Friedland et al.).

This way we emphasize the importance of a thorough clinical and radiographic exam because the more precocious is the diagnostic of the internal root resorptions the more successful can be the prognostic and the treatment.

ARAÚJO, L. C. G.; LINS, C. V.; LIMA, G. A.; TRAVASSOS, R. M. C. \& LINS, C. C. S. A. Estudio de la prevalencia de reabsorción interna en radiografías periapicales de dientes permanentes anteriores. Int. J. Morphol., 27(1):227-230, 2009.

RESUMEN: El objetivo del estudio fue evaluar, a través de fichas clínicas y radiológicas, la prevalencia nacional de reabsorción interna en los dientes anteriores permanentes de los pacientes con atención en la Clínica del Diplomado de Endodoncia de la Universidad Federal de Pernambuco, en el período entre septiembre de 2001 y junio de 2007. Se analizaron 888 prontuarios de los archivos de la Clínica. De ellos, 232 estaban relacionadas con los dientes anteriores. Se observó radiográficamente la presencia de reabsorción y su ubicación. Los resultados mostraron que la reabsorción interna fue prevalente en $2,16 \%$ de los casos, de los cuales en $0,86 \%$ estaba ubicada en la región coronaria, $0,44 \%$ en la raíz y $0,86 \%$ en ambas regiones. Se concluye que aún en caso de una enfermedad con baja incidencia, es importante para el especialista conocerla, haciendo un buen diagnóstico y una planificación para el tratamiento adecuado a la situación, ya que la de negligencia ante un caso de reabsorción interna en dientes permanentes anteriores, conduce a la pérdida del elemento dental, causando cambios funcionales y estéticos para el paciente.

PALABRAS CLAVE: Endodoncia; Reabsorción dental; Prevalencia.

\section{REFERENCES}

Andreasen, J. O. \& Andreasen, F. M. Root resorption following traumatic injuries. Proc. Finn. Dent Soc., 88:95-114, 1992.

Barbosa, S. V. Reabsorção dentária. In: Terapêutica endodôntica. $1^{a}$ ed.. São Paulo, Santos, 1999. p.254.

Cohenca, N.; Simon, J. H.; Mathur, A. \& Malfaz, J. M. Clinical indications for digital imaging in dento-alveolar trauma. Part 2: Root resorption. Dent. Traumatol., 23(2):105-13, 2007.
Côrtes, M. S. \& Bastos J. V. Lesões traumáticas da dentição permanente. In: Estrela, C. Ciência Endodôntica. $2^{\mathrm{a}}$ ed. São Paulo, Artes Médicas, 2004. pp.881-2.

Esberard, R. M.; Esberard, R. R. \& Esberard, C. B. Tratamento das reabsorções radiculares. In: Cardoso, R.J.A.; Gonçalves, E.A.N. Endodontia/Trauma. São Paulo, Artes Médicas, 2002. pp.425-43.

Friedland, B.; Faiella, R. A. \& Bianchi, J. Use of Rotational Tomography for Assessing Internal Resorption. $J$. 
ARAÚJO, L. C. G.; LINS, C. V.; LIMA, G. A.; TRAVASSOS, R. M. C. \& LINS, C. C. S. A. Study of prevalence of internal resorption in periapical radiography of anteriors permanents tooth. Int. J. Morphol., 27(I):227-230, 2009

Endod., 27(12):797-9, 2001.

Gunraj, M. N. \& Washington, M. S. Dental root resorption. Oral Surg. Oral Med. Oral Pathol., 88(6):647-53, 1999.

Hammarstron, L. \& Lindskog, S. General morphologic aspects of resortion of teeth and alveolar bone. Int. Endod. J., 1:93-108, 1985.

Hsien, H. C.; Cheng, Y. A.; Lee, Y. L.; Lan, W. H. \& Lin, C. $\mathrm{P}$. Repair of perforating internal resorption with mineral trioxide aggregate: A case report. J. Endod., 29(8):5389, 2003.

Kinomoto, Y.; Noro, T. \& Ebisu, S. Internal root resorption associated with inadequate caries removal and orthodontic therapy. J. Endod., 28(5):405-7, 2002.

Lopes, H. P.; Rôças, I. N. \& Siqueira Jr, J. F. Reabsorção dentária. In: Lopes, H. P. \& Siqueira Jr, J. F. Endodontia - Biologia e técnica. $2^{\mathrm{a}}$ ed. Rio de Janeiro, Guanabara Koogan, 2004. pp.837-70.

Lyroudia, K. M.; Dourou, V. I.; Pantelidou, O. C.; Labrianidis, T. \& Pitas, I. K. Internal root resorption studied by radiography, stereomicroscope, scanning electron microscope, and computerized 3D reconstructive method. Dent. Traumatol., 18:148-52, 2002.

Neville, B. W.; Damm, D. D. \& Bouquot, J. E. Patologia Oral e Maxilofacial. $2^{\mathrm{a}}$ ed. Rio de Janeiro, Guabara Koogan, 2004. pp.49-103.

Trope, M.; Chivian, N. \& Sigurdsson, A. Traumatismo dentário. In: Cohen, S. \& Burns, R. C. Caminhos da polpa. $7^{\mathrm{a} e d}$. Rio de Janeiro, Guanabara Koogan, 2000. pp.520-64.

Trope, M. Root resorption due to dental trauma. Endodotic Topics, 1:70-100, 2002.

Tsurumaki, A. M. Reabsorção Radicular Interna Aspectos Clínicos e Radiográficos, Diagnóstico Diferencial, Tratamento e Prognóstico. São Paulo, Associação Paulista de Cirurgiões Dentistas Escola de Aperfeiçoamento Profissional, 2004. p.54.
Correpondence to:

Prof. Carla Cabral dos Santos Accioly Lins Department of Anatomy

Universidade Federal de Pernambuco

Rua Manuel de Carvalho, 310, Apt301, Aflitos

CEP 52050-370

Recife- PE, BRASIL

Email: cabralcarla1@hotmail.com

Received: 10-06-2008

Accepted: 28-10-2008 